\title{
Biogas Production from Excess Sludge Oxidized with Peracetic Acid (PAA)
}

\author{
Iwona Zawieja *(1) and Małgorzata Worwąg (1)
}

check for updates

Citation: Zawieja, I.; Worwag, M. Biogas Production from Excess Sludge Oxidized with Peracetic Acid (PAA). Energies 2021, 14, 3434. https://doi.org/10.3390/en14123434

Academic Editors: Marcin Dẹbowski, Marcin Zieliński and Seung-Gu Shin

Received: 22 April 2021

Accepted: 7 June 2021

Published: 10 June 2021

Publisher's Note: MDPI stays neutral with regard to jurisdictional claims in published maps and institutional affiliations.

Copyright: (c) 2021 by the authors. Licensee MDPI, Basel, Switzerland. This article is an open access article distributed under the terms and conditions of the Creative Commons Attribution (CC BY) license (https:// creativecommons.org/licenses/by/ $4.0 /)$.
Faculty of Infrastructure and Environment, Czestochowa University of Technology, 42-200 Czestochowa, Poland; malgorzata.worwag@pcz.pl

* Correspondence: iwona.zawieja@pcz.pl

\begin{abstract}
Human functioning related to living and economic activity involves generating an increasing amount of sewage and sludge, which needs to be subjected to advanced processes of treatment, neutralization, and management. The deterioration in the susceptibility of excess sludge to biochemical decomposition observed under anaerobic conditions leads to the development and application of highly effective methods of wastewater treatment based on the removal of biogenic compounds using activated sludge, with a high degree of sludge thickening obtained in mechanical facilities. The concentration of volatile fatty acids, being an important intermediate product of anaerobic stabilization, directly determines biogas production efficiency. This study aimed to determine the effect of chemical disintegration with peracetic acid on biogas production efficiency using methane fermentation of pretreated sludge. Intensification of the hydrolysis phase is an important determinant of the efficiency of biochemical sludge decomposition under anaerobic conditions. The association of excess sludge oxidation, initiated by peracetic acid with biological hydrolysis, which is the first phase of methane fermentation, led to an increase in sludge digestion degree and biogas production efficiency. The compound of STERIDIAL W-10, which is an aqueous solution of $10 \%$ peracetic acid, $10 \%$ acetic acid, and $8 \%$ hydrogen peroxide, was used. The disintegration of excess sludge with a reactant dose of $3.0 \mathrm{~mL}$ of STERIDIAL W-10/L yielded a specific biogas production of $0.52 \mathrm{~L} / \mathrm{g}$ VSS and a $74 \%$ degree of sludge digestion.
\end{abstract}

Keywords: disintegration; peracetic acid (PAA); anaerobic stabilization; biogas; digestion degree

\section{Introduction}

Subjecting excess sludge to disintegration under the most favorable process conditions improves the effectiveness of methane fermentation. Depending on the energy supplied to the sludge, disintegration methods can be divided into mechanical, thermal, chemical, and biochemical (enzymatic) methods, as well as hybrid methods, which are a combination of the above [1].

According to literature data, chemical methods lead to oxidation and dissolution of organic compounds contained in sludge [2,3]. The application of pretreatment before anaerobic stabilization not only accelerates hydrolysis but also improves sludge susceptibility to biodegradation and dewatering, limits its foaming, and reduces the content of pathogens present in the sludge [4-11]. According to Sridhar Pilli et al. [12], the rate of biogas production is directly proportional to the sludge liquefaction factor.

Pretreatment of excess sludge using chemical reagents to break down single and clustered cells of microorganisms contained in the sludge leads to the release of intracellular organic matter into the liquid phase, and it also increases the availability of these substances to bacteria living in the sludge. Liquid substances in the hydrolysate are rich in organic compounds because fats and carbohydrates are converted into easily degradable forms, whereas proteins lose their protective enzymatic structure [13,14].

Based on data in the literature [15-17], it is known that the choice of reactant, its dose, and the appropriate time of its action have a great effect on the degree of disintegration. 
Chemical methods of disintegration using the energy of chemical reactions can be divided into the methods of advanced oxidation (based on the Fenton reaction, hydrogen peroxide, and ozone) and chemical methods using strong acid or alkali in amounts causing $\mathrm{pH}$ to reach close to extreme values $[18,19]$.

The chemical methods also include wet oxidation, which consists of sludge oxidation under conditions of elevated pressure. This process simultaneously involves the oxidation of organic compounds and thermohydrolysis, which is the main disintegrating agent [20-22].

Currently, methods based on the disinfecting power of oxidants such as ozone, hydrogen peroxide, chlorine, and chlorine dioxide are commonly used in sludge decomposition studies. Only a few researchers have used a combination of the effect of these reactants with anaerobic stabilization. An alternative to the above-mentioned reactants is the use of peracetic acid $[23,24]$, which is available on the chemical market in the form of an aqueous solution of acetic acid, peracetic acid, and hydrogen peroxide. Peracetic acid, with an oxidation potential of $1.81 \mathrm{eV}$, has many applications in the medical and food industry as a disinfectant and an oxidizing agent. As reported by Domínguez Henao et al. [25-27], in addition to its high efficacy, peracetic acid is characterized by no toxic degradation products. As a result of the action of PAA, low concentrations of DBP were observed, mainly carboxylic acids, which are not considered genotoxic. It was found that there is no evidence of endocrine or ecotoxicological disturbances of human health. Furthermore, it was observed that disinfected wastewater with PAA in the concentrations used typically in sewage treatment plants had limited toxic, mutagenic, or genotoxic effects on aquatic organisms.

Oxidation of organic compounds with peracetic acid occurs through the formation of hydroxyl radicals, which react with organic substances according to the following reaction:

$$
\mathrm{RH}+\mathrm{OH}^{*} \rightarrow \mathrm{H}_{2} \mathrm{O}+\mathrm{R}^{*}
$$

The resulting organic radical reacts with the other components [28].

According to Yoon et al. [29], hydroxyl radicals are efficient oxidizing agents formed by the Fenton reaction. According to the radical theory, the course of the Fenton reaction can be generally represented by the equation:

$$
\mathrm{Fe}^{2+}+\mathrm{H}_{2} \mathrm{O}_{2}+\mathrm{H}^{+} \rightarrow \mathrm{Fe}^{3+}+\mathrm{H}_{2} \mathrm{O}+\mathrm{OH}^{\bullet}
$$

However, the course of the Fenton reaction is complex.

Hydroxyl radicals formed in the Fenton reaction oxidize organic substances $(\mathrm{RH})$ and produce highly reactive organic radicals $\left(\mathrm{R}^{\bullet}\right)$ :

$$
\mathrm{RH}+\mathrm{HO}^{\bullet} \rightarrow \mathrm{H}_{2} \mathrm{O}+\mathrm{R}^{\bullet}
$$

According to Braun et al. [30], hydroxyl radicals can react with organic compounds in three ways:

- $\quad$ Through dehydrogenation, with this reaction usually taking place in unsaturated organic compounds:

$$
\mathrm{HO}^{\bullet}+\mathrm{RH} \rightarrow \mathrm{R}^{\bullet}+\mathrm{H}_{2} \mathrm{O}
$$

- Through electrophilic addition:

$$
\mathrm{HO}^{\bullet}+\mathrm{X}_{2} \mathrm{C}=\mathrm{CX}_{2} \rightarrow \mathrm{X}_{2} \mathrm{C}(\mathrm{OH})-\mathrm{C}^{\bullet} \mathrm{X}_{2}
$$

- $\quad$ Through electron transfer:

$$
\mathrm{HO}^{\bullet}+\mathrm{RX} \rightarrow \mathrm{XR}^{\bullet}+\mathrm{HO}^{-}
$$


The above-mentioned processes lead to the formation of organic radicals with an unpaired electron on the carbon atom (carbon radicals), which react with dissolved oxygen to produce peroxyl radicals according to the reaction:

$$
\mathrm{R}^{\bullet}+\mathrm{O}_{2} \rightarrow \mathrm{ROO}^{\bullet}
$$

Peracetic acid in an aqueous medium decomposes to water and acetic acid, which is a valuable substrate for methanogenic microorganisms responsible for biogas production.

According to Fleck et al. [28,31], peracetic acid causes the oxidation of a part of the organic suspension in the sludge with simultaneous inactivation of sludge microorganisms.

As demonstrated by Shang Meng et al. [32], sludge disintegration with peracetic acid at a concentration of $0.011 \%$ and a pretreatment time of $12 \mathrm{~h}$ leads to an approximately $72 \%$ increase in biogas production. Furthermore, the study by Appels et al. [33] showed that a dose of peracetic acid amounting to $25 \mathrm{~g} / \mathrm{kg}$ T.S. of sludge yielded a ca. $21 \%$ increase in biogas production.

It should be noted that sludge pretreatment with peracetic acid at the dose of peracetic acid of $40 \mathrm{~g} / \mathrm{kg}$ T.S. and higher, due to the high concentration of volatile fatty acids of $12,000 \mathrm{mg} \mathrm{CH} \mathrm{CH}_{3} \mathrm{COOH} / \mathrm{L}$, led to the deactivation of anaerobic microorganisms, consequently resulting in a decrease in biogas production intensity [34].

According to Neis [35], a maximum degree of ca. $40 \%$ sludge digestion can be achieved during conventionally conducted anaerobic stabilization of excess sludge. Therefore, the disintegration of excess sludge using peracetic acid is technologically advisable due to the possibility of an increase in the degree of sludge digestion, intensification, and shortening of the hydrolysis phase, and an increase in the efficiency of biogas generation.

In conclusion, an important advantage of peracetic acid disintegration is no secondary contamination of sludge due to the absence of toxic or mutagenic oxidation by-products or chemical residues [36,37]. The products of acetic acid breakdown are water and acetic acid [33]. The oxidation of organic compounds with peracetic acid occurs through the formation of hydroxyl radicals, which interact with organic compounds: $\mathrm{RH}+\mathrm{OH}^{*} \rightarrow$ $\mathrm{H}_{2} \mathrm{O}+\mathrm{R}^{*}$. However, the produced organic radicals $\mathrm{R}^{*}$ react with other components [33].

Therefore, the aim of this study was to determine the effect of chemical disintegration with PAA on biogas production efficiency using methane fermentation of the sludge after pretreatment. The novelty of the research is the application of a highly effective method of oxidation with the use of peracetic acid based on the most favorable treatment conditions to generate biogas from excess sludge. In this research, the most favorable conditions of sludge disintegration with peracetic acid were determined by analyzing changes in the $\mathrm{pH}$ value, alkalinity, acidity, dissolved chemical oxygen demand, and the concentration of volatile fatty acids. After the methane fermentation process, the degree of sludge digestion and biogas yield were determined while simultaneously conducting an analysis of daily biogas production intensity with consideration of the volumetric ratio of methane.

\section{Materials and Methods}

\subsection{Materials}

To achieve the aims of this study, excess sludge was used as a basic substrate in laboratory experiments concerning disintegration and in the next stage of conventional methane fermentation and assisted disintegration. Furthermore, during anaerobic stabilization, digested sludge was used as an inoculum. Sludge was collected from a mechanical and biological treatment plant at an increased nutrient removal rate. Due to the nature of the research, sludge from a large sewage treatment plant was selected for laboratory experiments, with the technology of sludge disposal allowing for potential implementation of the technological processes based on disintegration methods. A general characterization of selected physicochemical parameters determined for the sludge studied is presented in Table 1. 
Table 1. Characterization of the substrates in the study.

\begin{tabular}{|c|c|c|}
\hline \multirow{2}{*}{ Physicochemical Parameter/Unit } & \multicolumn{2}{|c|}{ Type of Sludge Used in the Experiment } \\
\hline & Excess Sludge & Digested Sludge (Inoculum) \\
\hline Total Solids (TS) & $12.35 \mathrm{~g} / \mathrm{L} \pm 0.23$ & $17.54 \mathrm{mg} / \mathrm{L} \pm 0.11$ \\
\hline Volatile Susprended Solids (VSS) & $9.12 \mathrm{~g} / \mathrm{L} \pm 0.16$ & $12.76 \mathrm{~g} / \mathrm{L} \pm 0.21$ \\
\hline Soluble chemical oxygen demand (SCOD) & $168 \mathrm{mg} \mathrm{O}_{2} / \mathrm{L} \pm 6$ & $1124 \mathrm{mg} \mathrm{O}_{2} / \mathrm{L} \pm 14$ \\
\hline Volatile fatty acids (VFAs) & $75 \mathrm{mg} \mathrm{CH}{ }_{3} \mathrm{COOH} / \mathrm{L} \pm 1.5$ & $692 \mathrm{mg} \mathrm{CH}{ }_{3} \mathrm{COOH} / \mathrm{L} \pm 3$ \\
\hline Alkalinity & $860 \mathrm{mg} \mathrm{CaCO}_{3} / \mathrm{L} \pm 5$ & $2760 \mathrm{CaCO}_{3} / \mathrm{L} \pm 10$ \\
\hline Kjeldahl nitrogen & $115 \mathrm{mg} \mathrm{N} / \mathrm{L} \pm 3.1$ & $732 \mathrm{mg} \mathrm{N} / \mathrm{L} \pm 2.3$ \\
\hline Ammonium nitrogen & $59 \mathrm{mg} \mathrm{N}-\mathrm{NH}_{4} / \mathrm{L} \pm 1.7$ & $582{\mathrm{mg} \mathrm{N}-\mathrm{NH}_{4}}^{+} / \mathrm{L} \pm 1.2$ \\
\hline $\mathrm{pH}$ & $7.03 \pm 0.05$ & $7.31 \pm 0.11$ \\
\hline
\end{tabular}

\subsection{Technological Examinations}

The research concerned the course of methane fermentation conducted in a conventional way and supported by chemical disintegration with peracetic acid (PAA).

The first stage of the research involved the disintegration of excess sludge with peracetic acid. A compound with the trade name STERIDIAL W-10 was used, which is an aqueous solution of $10 \%$ peracetic acid, $10 \%$ acetic acid, and $8 \%$ hydrogen peroxide. Selected doses of the tested reagent were used $(0.5 \div 8 \mathrm{~mL}$ STERIDIAL W-10/L), and the pretreatment times using the chemical method were $1,4 \mathrm{~h}$, and $8 \mathrm{~h}$. To chemically disintegrate the sludge, a mixture of excess sludge and reagent was pretreated at an appropriate dose selected for testing. Acid disintegration of sewage sludge was carried out at an ambient temperature in laboratory flasks protected from air and placed in a laboratory shaker.

The values of VFAs and SCOD were corrected by the value of these indices derived from the dose of peracetic acid, and acetic acid added into the sludge, which was the components of the reagent, i.e., STERIDIAL W-10, taking into account their percentage content in the solution and their density. As recommended by Appels et al. [33], it was assumed that peracetic acid was completely decomposed to acetic acid in the aqueous medium, and its value was calculated as $1.07 \mathrm{~g} \mathrm{O}_{2}=1 \mathrm{~g} \mathrm{CH}_{3} \mathrm{COOH}$.

The results were the basis for the determination of the most favorable pretreatment conditions, for which the highest value of soluble chemical oxygen demand (SCOD) and the highest increase in the concentration of volatile fatty acids (VFAs) was obtained.

In the second stage of the study, methane fermentation of non-pretreated sludge and the sludge subjected to chemical oxidation with peracetic acid was carried out. The 26-day anaerobic sludge stabilization was performed in a glass cylinder digester (Applicon, USA) with an active volume of $5 \mathrm{~L}$. The system was equipped with an installation for biogas collection and a device to ensure optimum mixing rate and to maintain a constant process temperature. A water jacket was placed outside to heat the sludge that fills the chamber. A platinum thermoelectrode placed inside the chamber ensured that the correct temperature was maintained. The stirrer had an option to control the rotational speed in the range of 0-1250 rpm. The mixing speed for all the processes carried out in the experiment was constant at $120 \mathrm{rpm}$. The system for biogas capture consistsed of a cylinder with an active volume of $2.5 \mathrm{~L}$ filled with a saturated sodium chloride solution and a $5 \mathrm{~L}$ compensation cylinder. Reading of the volume of the generated biogas collected in the cylinder was made based on the volume of the liquid displaced by the gas filling the vessel, with its excess (based on the principle of the communicating vessels) flowing into the compensation cylinder. The course of the fermentation was controlled every day based on gas production intensity. Figure 1 shows the digester with the installation used to control adequate mixing rate, maintain a constant process temperature, and capture the biogas. 


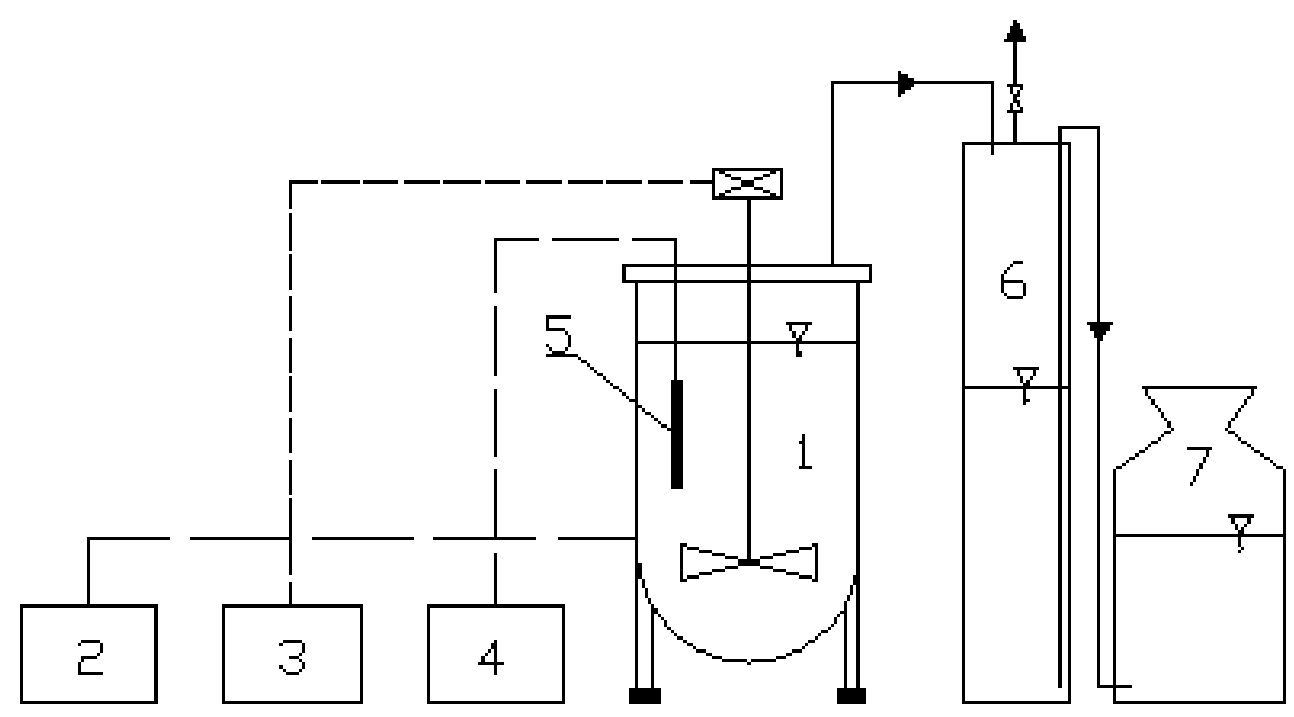

Figure 1. Diagram of the digester with instrumentation. (1) glass cylinder with an active volume of $5 \mathrm{dm}^{3}$, (2) heat exchanger, (3) mixing system, (4) temperature and $\mathrm{pH}$ control system, (5) measuring probe, (6) biogas tank, and (7) equalization tank.

The scope of the partial research tasks included:

- Determination of the impact of disintegration on the value of indices of susceptibility of the sludge to biodegradation;

- Determination of the effect of disintegration with peracetic acid on the structure of pretreated excess sludge;

- Determination of the effect of the disintegration carried out by a chemical method with the most favorable pretreatment conditions on the efficiency of anaerobic stabilization, i.e., biogas production intensity, methane content, and the degree of mineralization of excess sludge.

Mixtures of non-pretreated and disintegrated excess sludge were stabilized and inoculated with digested sludge to initiate the process, assuming a volumetric ratio of the above-mentioned sludge of 10:1.

The following mixtures of sludge were subjected to anaerobic stabilization:

- $\quad$ Sludge A: raw excess sludge + inoculum;

- Sludge B-excess sludge chemically disintegrated using an acidic reagent at a dose of $3 \mathrm{~mL}$ of STERIDIAL $\mathrm{W}-10 / \mathrm{L}$ for $1 \mathrm{~h}+$ inoculum.

The effectiveness of disintegration was evaluated based on the analysis of the following selected physicochemical parameters of the sludge:

- $\quad \mathrm{pH}$ using $\mathrm{pH}$ meter (Cole Palmer 59002-00), according to PN-9/C-04540/05 [38];

- Alkalinity and total acidity, according to PN-91/C-04540/05 [38];

- Soluble chemical oxygen demand (SCOD) by bichromate method using tests for HACH 2I00N IS spectrophotometer, according to ISO 7027 [39];

- Volatile fatty acids (VFA) by means of distillation with water vapor, according to PN-75/C-04616/04 [40].

The correctness and effectiveness of anaerobic stabilization of non-disintegrated and pretreated sludge were evaluated based on the following physicochemical determinations:

- Dry matter, dry organic matter, dry mineral matter according to PN-EN-12879 [41];

- $\quad \mathrm{pH}$ using pH meter (Cole Palmer 59002-00), according to PN-91/C-04540/05 [38];

- Soluble chemical oxygen demand (SCOD) by bichromate method using tests for HACH 2I00N IS spectrophotometer, according to ISO 7027 [39];

- Volatile fatty acids (VFA) by means of distillation with water vapor, according to PN-75/C-04616/04 [40];

- Total alkalinity, according to PN-91/C-04540/05 [38]; 
- Ammonium nitrogen, according to PN-73/C-04576/02 [42];

- Total Kjeldahl nitrogen, according to PN-73/C-04576/10 [43].

To evaluate disintegration efficiency, the liquefaction factor was determined using the methodology proposed by Zielewicz [44], Baier, and Schmidheiny [45] according to the following equation:

$$
\mathrm{F}_{\text {liq }}=\mathrm{SCOD}_{\mathrm{d}} / \mathrm{SCOD}_{0}
$$

where $\mathrm{F}_{\text {liq }}$ is the liquefaction factor; $\mathrm{SCOD}_{\mathrm{d}}$ is the soluble chemical oxygen demand determined in the filtrate after $0.45 \mu \mathrm{m}$ filter, for a sample after disintegration, $\mathrm{mgO}_{2} / \mathrm{L} ; \mathrm{SCOD}_{0}$ is the soluble chemical oxygen demand determined in the filtrate after $0.45 \mu \mathrm{m}$ filter, for a sample before disintegration, $\mathrm{mgO}_{2} / \mathrm{L}$.

Microscopic observations of the change in sludge structure were made at the stage of disintegration. The microscopic images obtained for the sludge subjected to the abovementioned treatment processes provided, in addition to the values of selected physicochemical determinations of the sludge, an additional tool for the assessment of the efficiency of disintegration, and consequently the potential efficiency of methane fermentation. Microscopic observations of the structure of unprocessed and pretreated excess sludge were performed using an Olympus BX 41 microscope with instrumentation for taking photographs. Microphotographs were taken at $500 \times$ magnification, and the assessment of changes in the structure of excess sludge was made using a visual method taking into account selected morphological features of the sludge.

The degree of digestion of the sludge tested was calculated according to PN-75/C04616/07 [46]. The volume of biogas produced during methane fermentation was converted to standard conditions, according to the Polish standard PN-75/C-04616/07 [45]. On the other hand, biogas yield (BY) was determined according to equation [47]:

$$
\mathrm{BY}=\left(\sum \mathrm{n}\right) /\left(\Delta \mathrm{f} \_\mathrm{u}\right)
$$

where BY is the biogas yield, L/g VSS; $\sum \mathrm{n}$ is the sum of biogas volume obtained during fermentation reduced to normal conditions, L; $\Delta \mathrm{fu}$ is the loss of VSS in the sludge, $\mathrm{g}$ VSS.

Furthermore, the composition of the biogas produced was monitored at one-day intervals during methane fermentation. A GA 2000 analyzer (Geotechnical Instruments) was used to determine the percentage of methane in biogas. For selected parameters, the standard deviation was determined, with its value presented on graphs. Selected determinations were repeated three times during the research. For each value in the dataset, the deviation of this value from the mean was calculated, and the deviation is shown using the symbol $\pm[48]$.

Table 2 presents the characteristics of the research stages carried out.

\begin{tabular}{|c|c|c|c|}
\hline SUBSTRATES & STAGE I & \multicolumn{2}{|c|}{ STAGE II } \\
\hline $\begin{array}{c}\text { Excess Sludge } \\
\text { Digested Sludge (Inoculum) } \\
\text { (Ratio 10:1) }\end{array}$ & $\begin{array}{l}\text { Excess Sludge Pretreatment } \\
(0.5 \div 8 \mathrm{~mL} \text { STERIDIAL W-10/L } \\
\text { Sludge; Pretreatment Time: } 1 \\
4 \mathrm{~h} \text {, and } 8 \mathrm{~h}\end{array}$ & $\begin{array}{l}\text { Methane Fermentation of } \\
\text { Sludge A } \\
\text { (Time of Process: } 26 \mathrm{~d}) \\
\text { Excess Sludge + Inoculum (10:1) }\end{array}$ & $\begin{array}{c}\text { Methane Fermentation of } \\
\text { Sludge B } \\
\text { (Time of Process: } 26 \mathrm{~d} \text { ) } \\
\text { Excess Sludge Chemically } \\
\text { Disintegrated Using an Acidic } \\
\text { Reagent at a Dose of } 3 \mathrm{~mL} \text { of } \\
\text { STERIDIAL W-10/L Sludge for } \\
1 \mathrm{~h}+\text { Inoculum (10:1) }\end{array}$ \\
\hline \multicolumn{4}{|c|}{ Selected physicochemical parameters: } \\
\hline $\begin{array}{l}\text { TS, VSS, SCOD, VFAs, Alkalinity, } \\
\text { Kjeldahl nitrogen, Ammonium } \\
\text { nitrogen, and } \mathrm{pH}\end{array}$ & $\begin{array}{l}\mathrm{pH}, \text { Alkalinity, Acidinity, SCOD, } \\
\text { VFAs, and } \mathrm{F}_{\text {liq. }}\end{array}$ & \multicolumn{2}{|c|}{$\begin{array}{c}\text { TS, VSS, SCOD, VFAs, Alkalinity, } \\
\text { Kjeldahl nitrogen, Ammonium nitrogen, } \mathrm{pH} \text {, VFAs/Alkalinity, biogas } \\
\text { production intensity, methane content in biogas, and sludge } \\
\text { digestion degree }\end{array}$} \\
\hline
\end{tabular}

Table 2. Characteristics of research stages. 


\section{Results and Discussion}

3.1. The Effect of the Disintegration Conducted Using Independent Methods on Indices of Biodegradability of Sewage Sludge

In this section, the effect of acidic chemical disintegration on the increase in biodegradability of pretreated sludge was determined. The most favorable pretreatment conditions were determined based on the increase in soluble chemical oxygen demand (SCOD) and volatile fatty acids (VFAs) concentration. Furthermore, the $\mathrm{pH}$ of the pretreated sludge and its acidity and alkalinity were determined for selected samples. To determine the most favorable conditions of acid disintegration, the reagent dose was chosen at the assumed pretreatment times of 1,4 , and $8 \mathrm{~h}$. The correctness of the choice of the most favorable conditions for sludge pretreatment was additionally confirmed by the value of the sludge liquefaction factor, which was reflected in the observed change in the structure of the pretreated sludge. The values obtained for repeated measurements of individual physicochemical parameters were not differentiated. It was found that in the case of statistical deviation determined for all measurements, the obtained results showed a slight deviation from the mean.

\subsubsection{Increase in the Concentration of Dissolved Organic Matter Observed in the} Supernatant Liquor of Chemically Disintegrated Sewage Sludge

Based on the results, it was found that an increase in the reagent dose had a decisive impact on the increase in the values of indices determining the biodegradability of pretreated sludge, i.e., SCOD and VFAs. Furthermore, a decrease in $\mathrm{pH}$ was observed after the addition of an acidic reagent to the sludge (Figure 2). For the dose range studied and pretreatment time of $1 \mathrm{~h}$, the $\mathrm{pH}$ value ranged from 4.27 to 7.49 ; for the pretreatment time of $4 \mathrm{~h}$, they ranged from 3.93 to 7.42 , while for the $8 \mathrm{~h}$ pretreatment-from 3.54 to 7.26 .

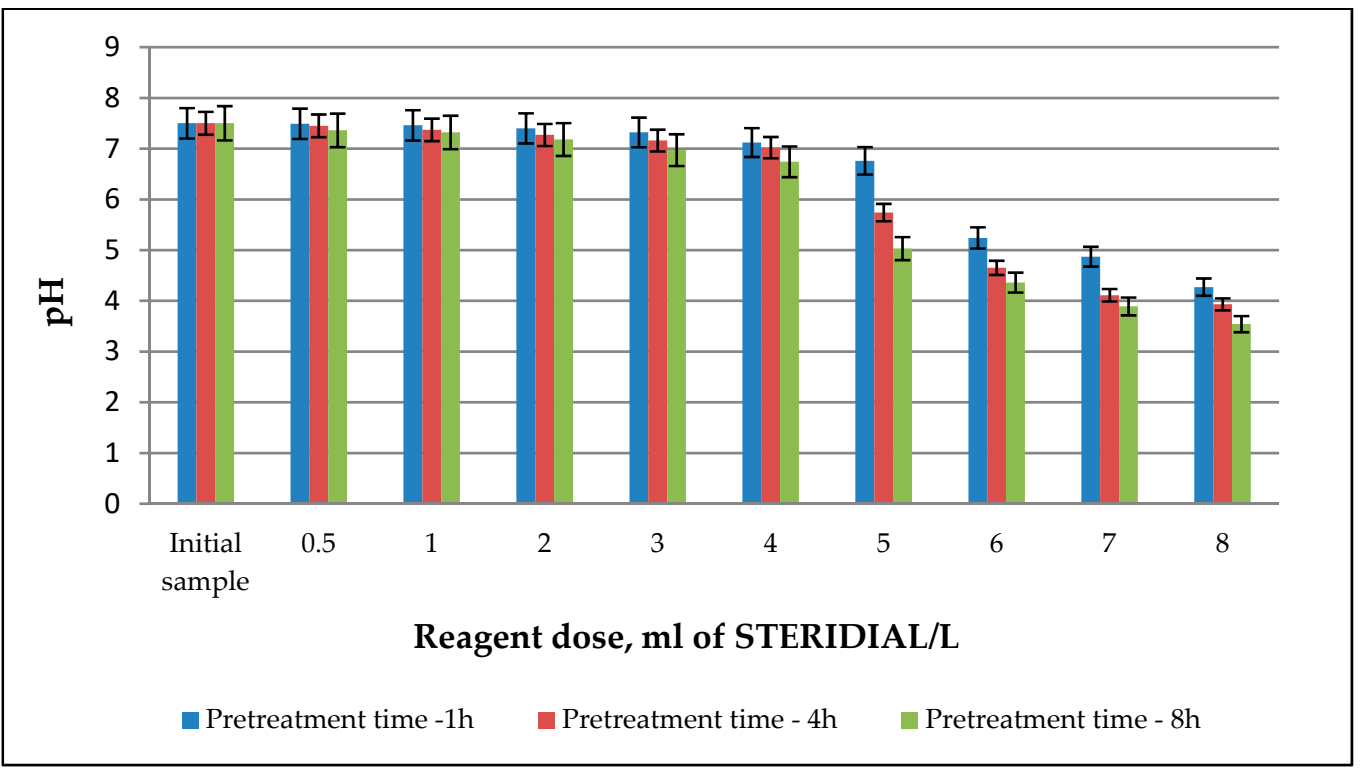

Figure 2. Changes in $\mathrm{pH}$ values determined in the sludge liquor subjected to 1,4 , and $8 \mathrm{~h}$ chemical disintegration of excess sludge vs. reagent dose.

According to Procházka et al. [49], the insignificant impact of PAA on the excess sludge $\mathrm{pH}$ could be caused by buffering capacity, that is, equilibrium between ammonium, carbonate, and volatile fatty acids (e.g., acetic, propanoic, and butyric acids). An increasing trend was observed in the case of the total acidity of the sludge pretreated with the reagent in the range of doses of $0.5 \div 8 \mathrm{~mL}$ of STERIDIAL $\mathrm{W}-10 / \mathrm{L}$, with values of $37 \div 1167 \mathrm{mg}$ $\mathrm{CO}_{2} / \mathrm{L}$ for the pretreatment time of $1 \mathrm{~h}, 42 \div 1318 \mathrm{mg} \mathrm{CO} / \mathrm{L}$ for the pretreatment time of $4 \mathrm{~h}$, and $45 \div 1427 \mathrm{CO}_{2} / \mathrm{L}$ for the pretreatment time of $8 \mathrm{~h}$ (Figure 3 ). 


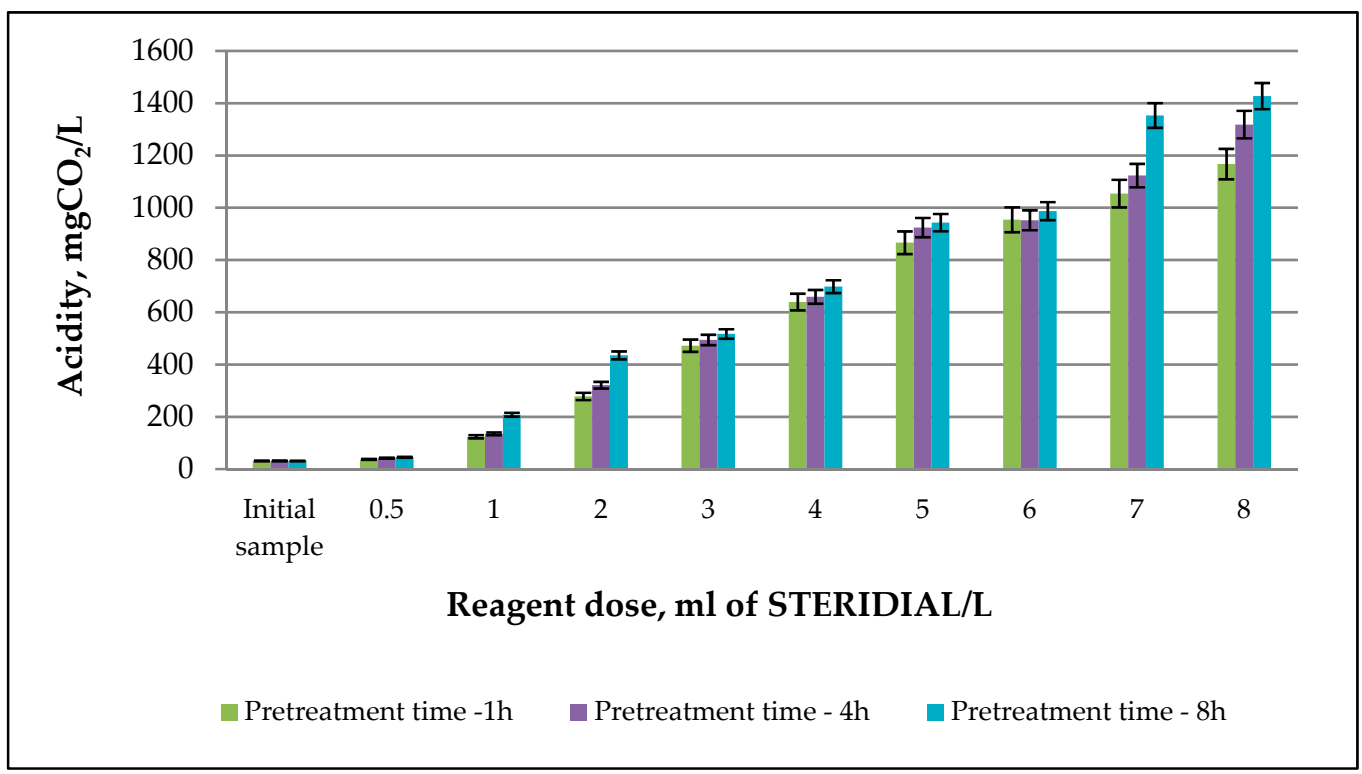

Figure 3. Changes in acidity determined in the sludge liquor subjected to 1,4 , and $8 \mathrm{~h}$ chemical disintegration of excess sludge vs. reagent dose.

A decreasing trend was observed for total alkalinity determined in the case of pretreated sludge, with values ranging from 380 to $880 \mathrm{mg} \mathrm{CaCO} / \mathrm{L}$ for $1 \mathrm{~h}, 320$ to $880 \mathrm{mg}$ $\mathrm{CaCO}_{3} / \mathrm{L}$ for $4 \mathrm{~h}$, and 280 to $840 \mathrm{mg} \mathrm{CaCO} / \mathrm{L}$ for $8 \mathrm{~h}$ (Figure 4 ).

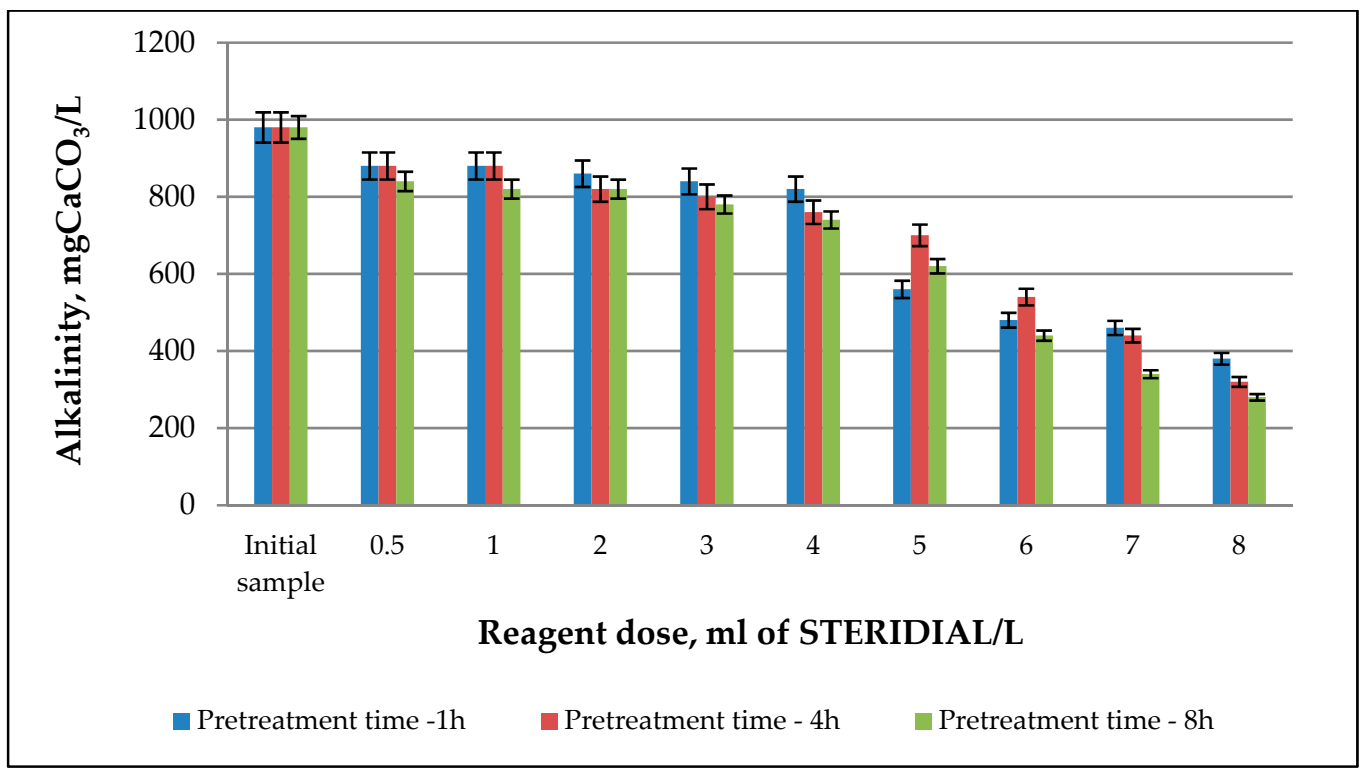

Figure 4. Changes in acidity determined in the sludge liquor subjected to 1,4 , and $8 \mathrm{~h}$ chemical disintegration of excess sludge vs. reagent dose.

As a result of 1,4 , and $8 \mathrm{~h}$ of sludge disintegration by addition of STERIDIAL W-10 solution in doses ranging from $0.5 \div 8 \mathrm{~mL} / \mathrm{L}$, an increase in the soluble chemical oxygen demand (SCOD) values was from 256 to $4157 \mathrm{mg} \mathrm{O}_{2} / \mathrm{L}$ for the pretreatment time of $1 \mathrm{~h}$, from 324 to $4638 \mathrm{mg} \mathrm{O}_{2} / \mathrm{L}$ for $4 \mathrm{~h}$, and from 332 to $4698 \mathrm{mg} \mathrm{O}_{2} / \mathrm{L}$ for $8 \mathrm{~h}$ with respect to the lowest and the highest reagent doses, respectively (Figures 5-7). Based on the results obtained, Cavallini et al. [50] concluded that PAA leads to an increase in the concentration of dissolved organic matter, resulting in an increase in chemical oxygen demand in sewage by approximately $20 \mathrm{mg} / \mathrm{L}$ for every $10 \mathrm{mg} / \mathrm{L}$ of PAA used. As the reagent dose increased, a gradual increase in the concentration of volatile fatty acids determined in the supernatant 
liquid of the pretreated sludge was noted. For the tested reagent doses of $0.5 \div 8 \mathrm{~mL}$ STERIDIAL W-10/L, a 1.1-fold to 20.4-fold increase in the VFA concentration for the pretreatment time of $1 \mathrm{~h}, 1.4$-fold to 26.3-fold for $4 \mathrm{~h}$, and 1.6-fold to 26.6-fold for $8 \mathrm{~h}$, were obtained with respect to the VFA concentration values of the non-pretreated sludge (Figures 5-7). According to data in the literature [28,30,31], chemical disintegration with peracetic acid promotes the formation of highly reactive hydroxyl radicals, which is an important oxidizing agent during chemical pretreatment.

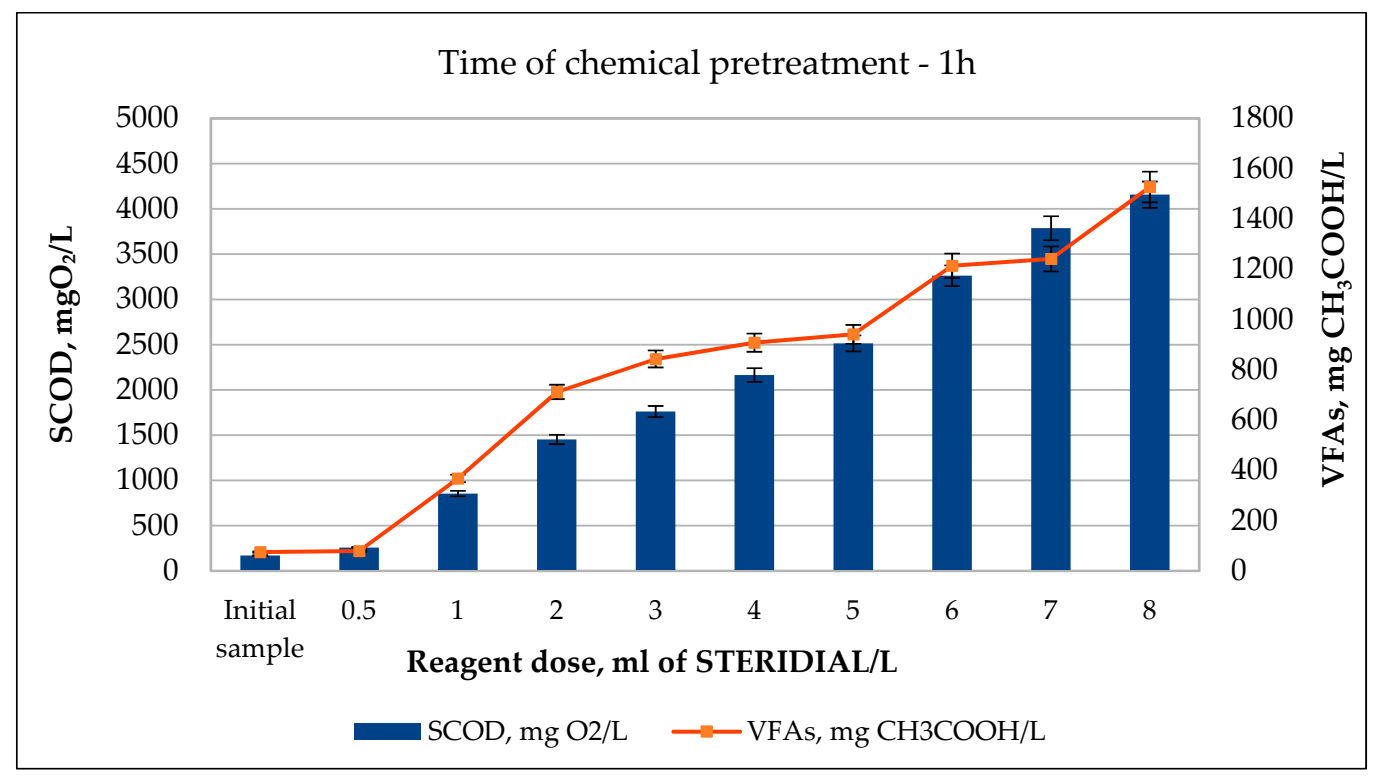

Figure 5. Changes in soluble chemical oxygen demand (SCOD) and concentration of volatile fatty acids (VFAs) determined in the supernatant liquor of chemically disintegrated excess sludge (pretreatment time: $1 \mathrm{~h}$ ) recorded in relation to the reagent doses used.

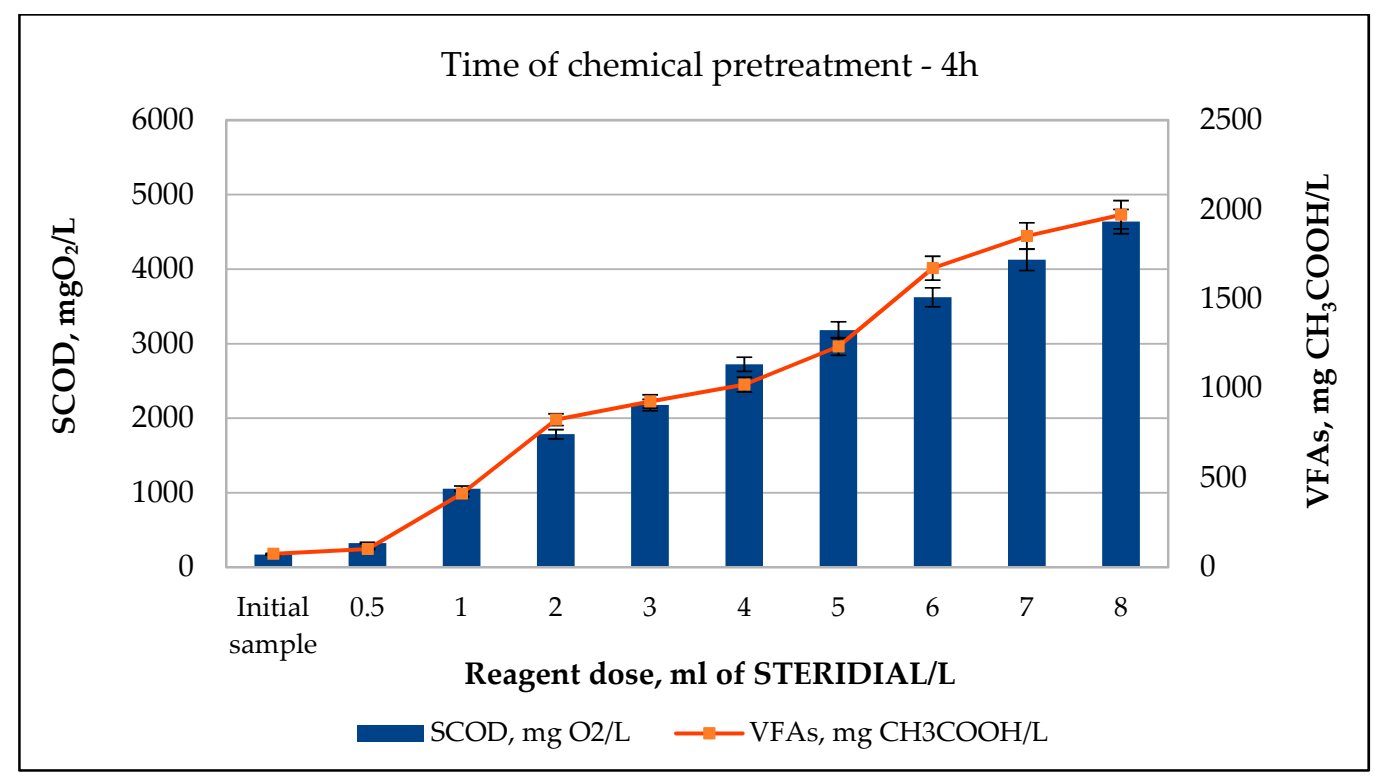

Figure 6. Changes in soluble chemical oxygen demand (SCOD) and concentration of volatile fatty acids (VFAs) determined in the supernatant liquor of chemically disintegrated excess sludge (pretreatment time: $4 \mathrm{~h}$ ) recorded in relation to the reagent doses used. 


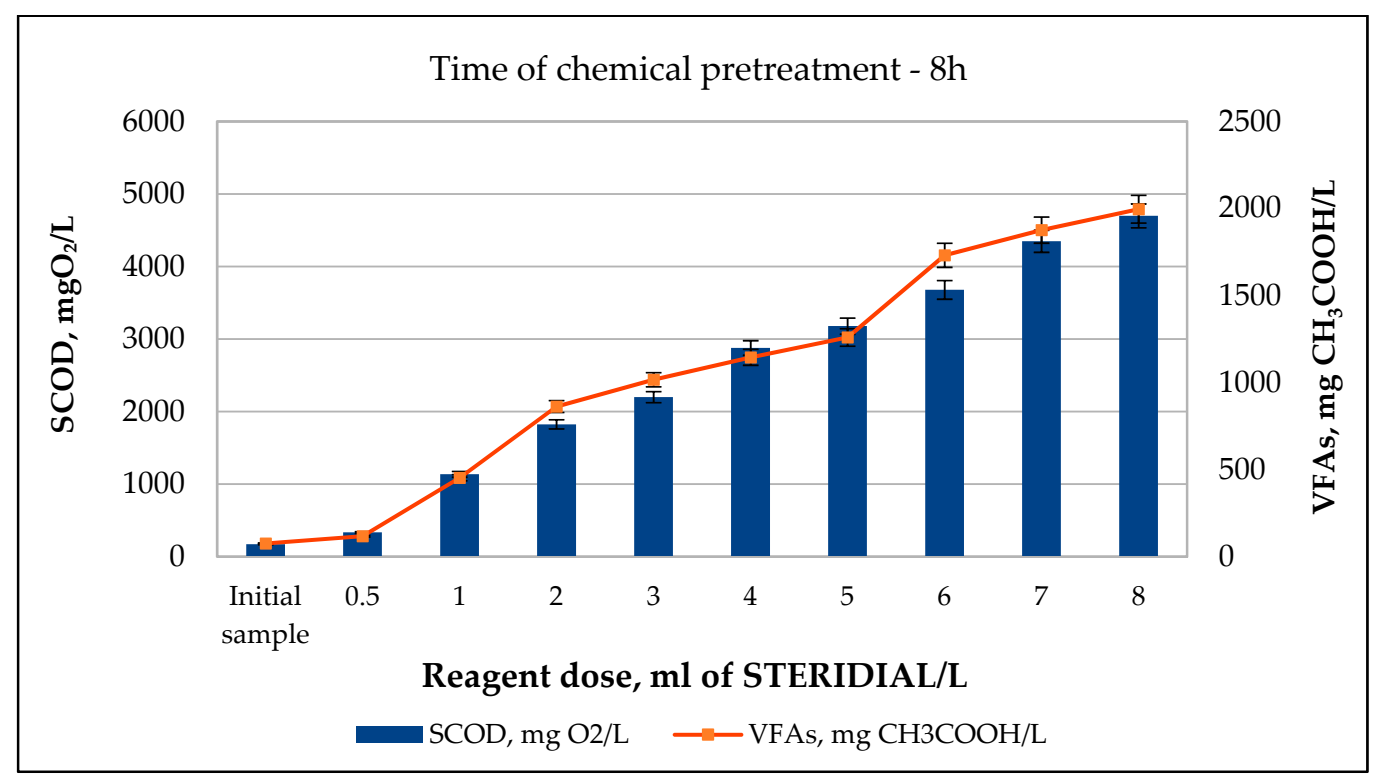

Figure 7. Changes in soluble chemical oxygen demand (SCOD) and concentration of volatile fatty acids (VFAs) determined in the supernatant liquor of chemically disintegrated excess sludge (pretreatment time: $8 \mathrm{~h}$ ) recorded in relation to the reagent doses used.

As a result of the disintegration of sludge by adding STERIDIAL W-10 solution in doses ranging from 0.5 to $8 \mathrm{~mL} / \mathrm{L}$, the values of the liquefaction factor were 1.5 to 24.7 for the pretreatment time of $1 \mathrm{~h}, 1.9$ to 27.6 for the pretreatment time of $4 \mathrm{~h}$, and 2.0 to 28.0 for the pretreatment time of $8 \mathrm{~h}$. It was observed that for the reagent doses tested, similar values of the sludge liquefaction factor were obtained for greater treatment times (Figure 8).

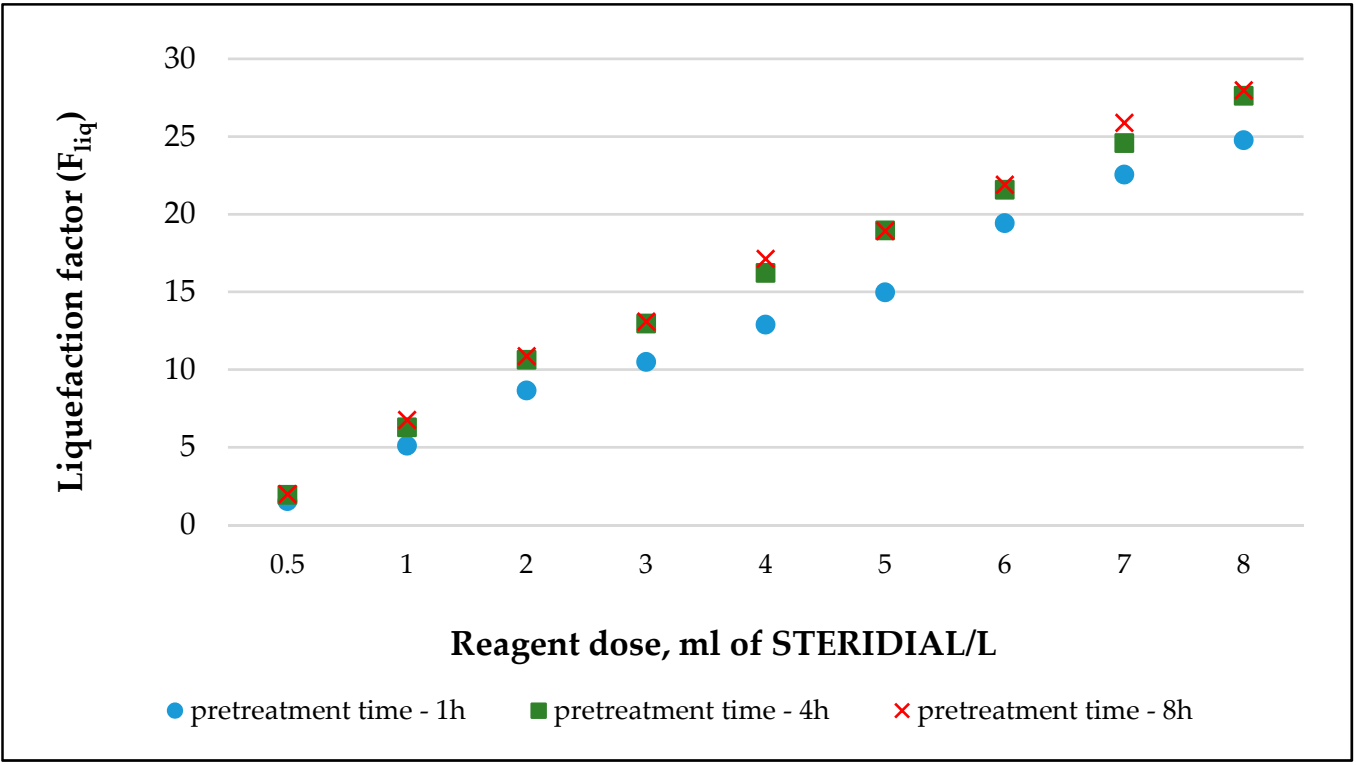

Figure 8. Changes in the value of the liquefaction factor determined in the supernatant liquid of chemically disintegrated excess sludge (pretreatment time 1, 4, and $8 \mathrm{~h}$ ).

Due to the technological conditions of the anaerobic stabilization process, a reagent dose of $3.0 \mathrm{~mL}$ of STERIDIAL W-10/L of sludge was selected for further experiments, for which, along with the subsequent increase in sludge biodegradability, there was no need to modify the $\mathrm{pH}$ of the sludge treated. In the case of higher doses, a correction of the $\mathrm{pH}$ value would be necessary and would cause secondary contamination of the treated medium. The reagent dose of $3 \mathrm{~mL}$ of STERIDIAL W-10/L, and the pretreatment time of 1 
$\mathrm{h}$ were found to be the most favorable pretreatment conditions. According to Domínguez Henao et al. [25-27], regarding the kinetics of the changes induced by peracetic acid, the value of the rate constant and the initial consumption of PAA increases with increasing content of organic matter. Therefore, the half-life of PAA dosed to sludge is short, with a large amount of suspended solids.

\subsubsection{Structure of Chemically Disintegrated Excess Sludge}

The measurable effect of disintegrating factors is the observed change in the structure of pretreated sludge, with its nature determining sludge susceptibility to biochemical decomposition in anaerobic conditions. Changes in the structure of excess sludge subjected to peracetic acid pretreatment recorded during microscopic observations correlate with the value of the liquefaction factor $\left(\mathrm{F}_{\mathrm{liq}}\right)$, which can be considered an additional research tool confirming the effectiveness of the selected disintegration method. Intensification of sludge particle liquefaction was observed with an increase in the reactant dose (Figure 9).

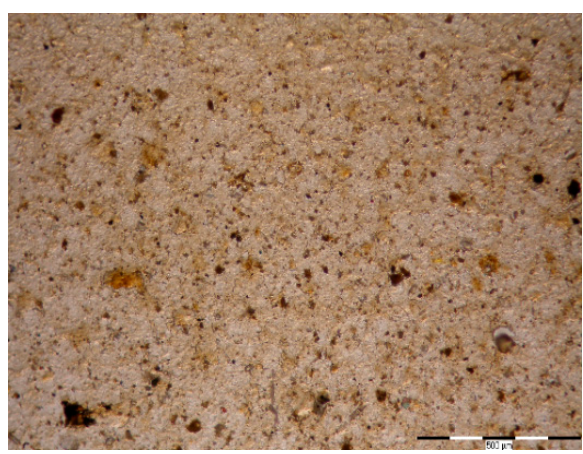

(a)

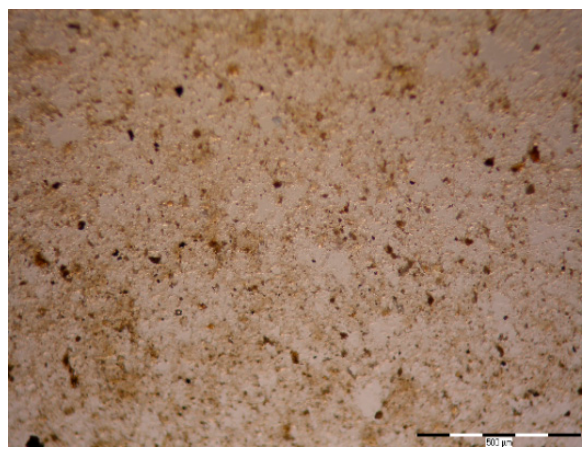

(c)

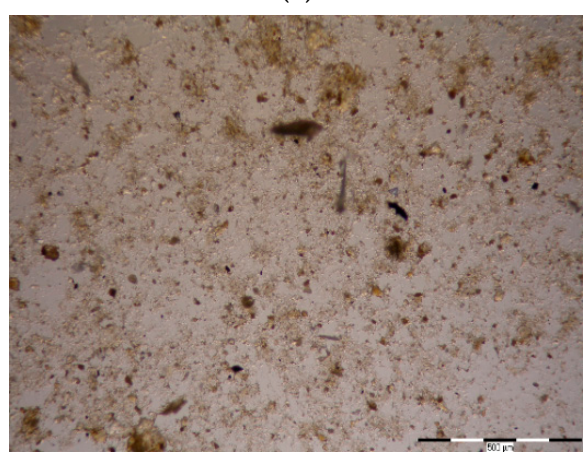

(e)

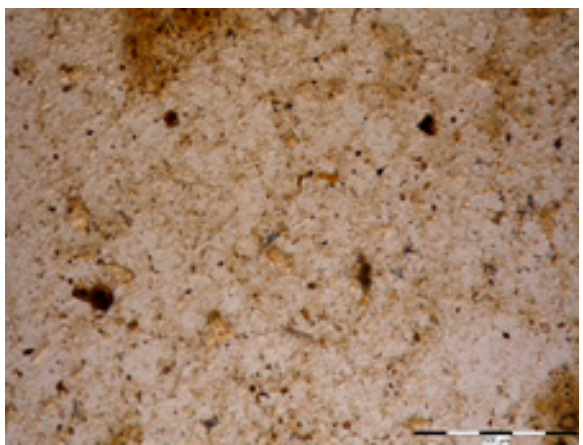

(b)

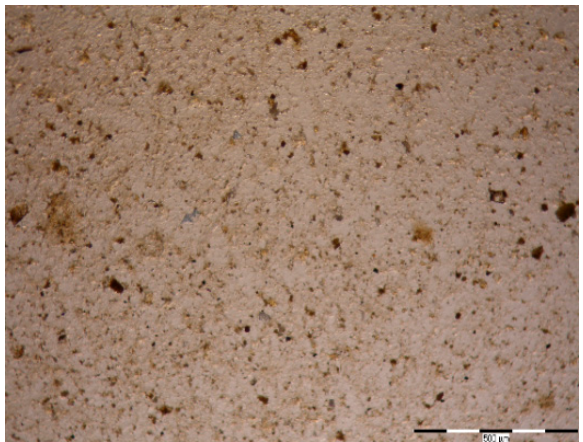

(d)

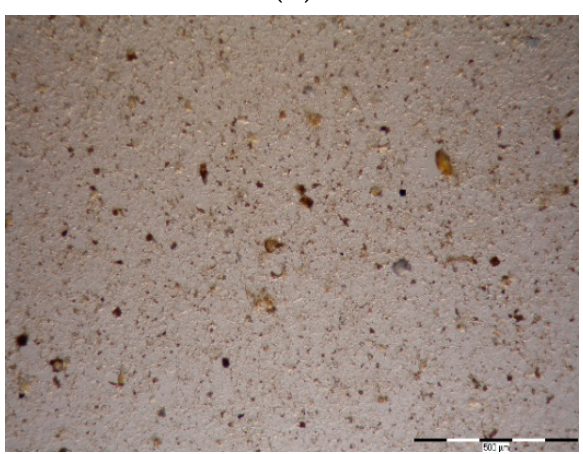

(f)

Figure 9. Structure of non-pretreated excess sludge (a) and structure of excess sludge chemically disintegrated with the reagent with the selected doses: $0.5 \mathrm{~mL}$ STERIDIAL W-10/L (b), $1.0 \mathrm{~mL}$ STERIDIAL W-10/L (c), 2 mL STERIDIAL W-10/L (d), 3 mL STERIDIAL W-10/L (e), and 8 mL STERIDIAL W-10/L (f) sludge for $1 \mathrm{~h}$. 
3.2. Effect of Disintegration on the Efficiency of Anaerobic Stabilization, i.e., Volatile Fatty Acids Generation, Biogas Production Intensity, Methane Content, and Sludge Digestion Degree

The choice of the most favorable conditions for chemical disintegration with peracetic acid was based on the effectiveness of the disintegration method tested, i.e., the increase in VFA concentration, SCOD value, and the liquefaction factor $\left(\mathrm{F}_{\text {liq }}\right)$, also taking into account the $\mathrm{pH}$ value, acidity, and alkalinity, which determine the correct course of methane fermentation. Therefore, for technological reasons, a reactant dose of $3 \mathrm{~mL}$ of STERIDIAL $\mathrm{W}-10 / \mathrm{L}$ and a pretreatment time of $1 \mathrm{~h}$ were chosen for further experiments. Due to the buffering properties of the sludge, the application of the above-mentioned reagent dose did not cause a significant decrease in $\mathrm{pH}$ value and did not require any correction of this indicator to the optimal value for methane fermentation. It should be noted that the $\mathrm{pH}$ affects solubility and forms of both organic and inorganic compounds. It also determines the proper development of fermentation microorganisms, especially methanogens. According to Magrel [51], the $\mathrm{pH}$ of the supernatant liquid should be $7.0 \div 7.2$. The $\mathrm{pH}$ limits should be between 6.5 and 8.5. [51,52]. The disintegration of the excess sludge with $3 \mathrm{~mL}$ of STERIDIAL W-10/L and a pretreatment time of $1 \mathrm{~h}$ resulted in a $\mathrm{pH}$ value of 6.78 .

In the first research cycle, a conventional methane fermentation was carried out (Mixture A), while in the next, chemically disintegrated sludge was subjected to methane fermentation using a dose of $3 \mathrm{~mL}$ of STERIDIAL W-10/L (Mixture B). Chu et al. [53] argued that disintegration of excess sludge leads directly affects the acceleration and leads to the shortening of the time needed for stabilization to about 8 days and increasing the rate of biogas production and unit biogas production. Figure 10 shows the changes in the concentration of volatile fatty acids during 8-day conventional methane fermentation and methane fermentation of sludge treated with peracetic acid (PAA).

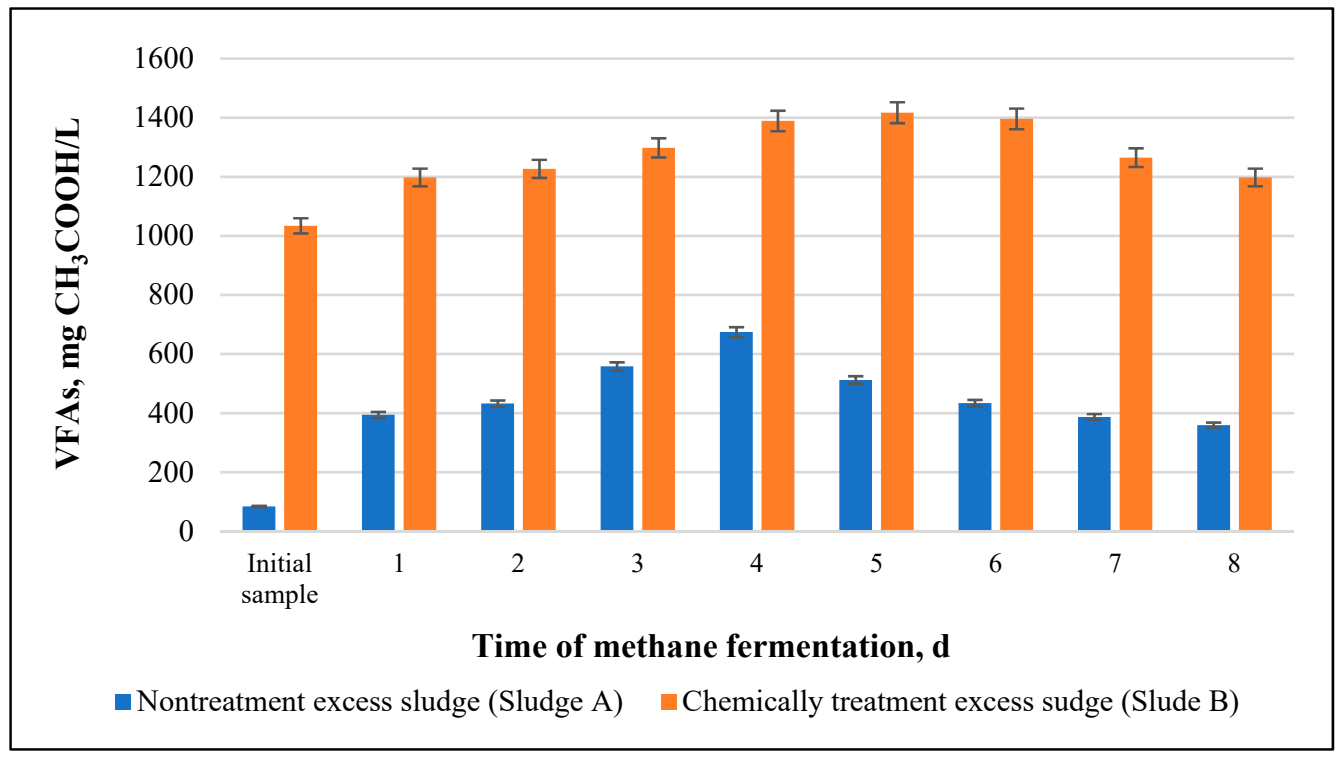

Figure 10. Generation of volatile fatty acids (VFAs) from excess sludge during methane fermentation.

With the changes taking place in the physicochemical and structural properties of the disintegrated sludge, an increase in the amount and rate of production of volatile fatty acids (VFAs) was observed at the stage of sludge acid digestion compared to the anaerobic stabilization of pretreated sludge. The combination of acid hydrolysis caused by the introduction of peracetic acid (PAA) and biological hydrolysis, which is the first phase of methane fermentation, resulted in an increase in the efficiency of anaerobic stabilization compared to the efficiency of stabilization of the non-pretreated sludge. According to data in the literature [19], hydrolysis in conventional systems of sludge treatment based on anaerobic processes has a decisive effect on the rate of methane fermentation, and it takes place with the participation of exoenzymes produced by microorganisms. 
Table 3 shows selected physicochemical parameters obtained for conventional methane fermentation and methane fermentation of the sludge after disintegration.

Table 3. Selected physicochemical parameters obtained for sludge A and B subjected to 26-day methane fermentation.

\begin{tabular}{|c|c|c|c|c|}
\hline \multirow{2}{*}{ Index/Unit } & \multicolumn{2}{|c|}{ Sludge A } & \multicolumn{2}{|c|}{ Sludge B } \\
\hline & Day 0 of Process & Day 26 of Process & Day 0 of Process & Day 26 of Process \\
\hline TS, g/L & $12.54 \pm 0.11$ & $9.26 \pm 0.17$ & $12.76 \pm 0.36$ & $7.18 \pm 0.17$ \\
\hline VSS, g/L & $9.21 \pm 0.32$ & $4.34 \pm 0.25$ & $9.22 \pm 0.53$ & $2.37 \pm 0.21$ \\
\hline Alkalinity, mg $\mathrm{CaCO}_{3} / \mathrm{L}$ & $880 \pm 15$ & $2420 \pm 40$ & $920 \pm 20$ & $2640 \pm 10$ \\
\hline $\mathrm{SCOD}, \mathrm{mg} \mathrm{O}_{2} / \mathrm{L}$ & $185 \pm 8$ & $842 \pm 3$ & $1792 \pm 7$ & $1034 \pm 11$ \\
\hline VFAs, mg $\mathrm{CH}_{3} \mathrm{COOH} / \mathrm{L}$ & $83 \pm 2.1$ & $617 \pm 5.5$ & $912 \pm 3$ & $834 \pm 4$ \\
\hline Kjeldahl nitrogen, mg N/dm ${ }^{3}$ & $134 \pm 4.3$ & $585 \pm 4.8$ & $415 \pm 2.1$ & $617 \pm 6.5$ \\
\hline Ammonium nitrogen, $\mathrm{mg} \mathrm{N}-\mathrm{NH}^{4} / \mathrm{dm}^{3}$ & $69 \pm 0.5$ & $507 \pm 1.6$ & $134 \pm 4.6$ & $583 \pm 1.8$ \\
\hline $\mathrm{pH}$ & $7.1 \pm 0.04$ & $7.31 \pm 0.05$ & $7.06 \pm 0.03$ & $7.24 \pm 0.06$ \\
\hline VFAs/Alkalinity & - & 0.25 & - & 0.32 \\
\hline
\end{tabular}

The SCOD values of $842 \mathrm{mg} \mathrm{O}_{2} / \mathrm{L}$ and $1034 \mathrm{mg} \mathrm{O}_{2} / \mathrm{L}$ and concentrations of volatile fatty acid (VFAs) of $617 \mathrm{mg} \mathrm{CH}{ }_{3} \mathrm{COOH} / \mathrm{L}, 834 \mathrm{mg} \mathrm{CH}{ }_{3} \mathrm{COOH} / \mathrm{L}$ were recorded for sludge $\mathrm{A}$ and $\mathrm{B}$ on day 26 of the process, respectively. On the other hand, on the day of the process initiation (Day 0), the values of the examined indices were $185 \mathrm{mg}$ and $1792 \mathrm{mg} \mathrm{O}_{2} / \mathrm{L}$ and 83 and $912 \mathrm{mg} \mathrm{CH} \mathrm{CH}_{3} \mathrm{COOH} / \mathrm{L}$, respectively. Stabilization of sludge A yielded ca. 53\% sludge digestion degree and ca. $42 \%$ reduction in dry matter, while for sludge B, sludge digestion degree was ca. $74 \%$, and the reduction in dry matter was ca. $56 \%$. The $\mathrm{pH}$ value at the beginning of the process (Day 0) was 7.1 for sludge A; and 7.06 for sludge $B$, reaching 7.31 and 7.24 on day 26. During the 26-day stabilization, the initial and final alkalinity values were 880 and $2420 \mathrm{CaCO}_{3} / \mathrm{L}$ for sludge $\mathrm{A}$ and 920 and $2640 \mathrm{CaCO}_{3} / \mathrm{L}$ for sludge B, respectively. The VFAs/alkalinity quotient on day 26 was 0.25 (sludge A) and 0.32 (sludge $\mathrm{B}$ ). The values of Kjeldahl nitrogen and ammonium nitrogen on the day of process initiation (day 0) and after 26 days of stabilization of the sludge A were 134

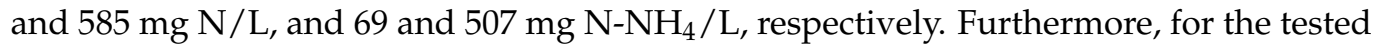
sludge $\mathrm{B}$, the values of Kjeldahl nitrogen and ammonium nitrogen at the day of the process initiation (day 0 ) and after 26 days of stabilization were 415 and $617 \mathrm{mg} \mathrm{N} / \mathrm{L}$, and 134 and $583 \mathrm{mg} \mathrm{N}-\mathrm{NH}_{4} / \mathrm{L}$, respectively.

During methane fermentation of sludge subjected to chemical disintegration with a reactant dose of $3.0 \mathrm{~mL}$ of STERIDIAL W-10/L (sludge B), the highest value of daily biogas production $(0.28 \mathrm{~L})$ was observed on the 10th day of the process. Total biogas production of $3.53 \mathrm{~L}$ was recorded, which translated into a specific biogas production of $0.52 \mathrm{~L} / \mathrm{g}$ VSS. In the case of the conventional sludge methane fermentation (sludge A), the highest value of daily biogas production $(0.12 \mathrm{~L}$ ) was observed on day 12 . A total biogas production of $0.97 \mathrm{~L}$ was recorded, which translated into specific biogas production of $0.2 \mathrm{~L} / \mathrm{g}$ VSS. According to the literature data [45], biogas production efficiency can be determined with reference to the volume of the digester expressed in $\mathrm{m}^{3}$, the volume of biogas per one inhabitant, or by defining the volume of biogas obtained from the removal of a load of pollutants contained in the sludge expressed as dry organic matter, i.e., biogas yield (L/g VSS).

Based on research results, Sun et al. [54] found that with regard to the methane fermentation of untreated sludge, the cumulative biogas production increased by $20.0 \%$ after 26 days of anaerobic digestion of the sludge subjected to oxidation with peracetic acid. The biogas production rate in the digester with pretreated sludge reached the maximum on day 8 at $87 \mathrm{~mL} / \mathrm{d}$, but the peak value was obtained on day 11 at $74 \mathrm{~mL} / \mathrm{d}$ in the case of non-pretreatment sludge. Therefore, based on the results obtained in the present study and those obtained by other scientists $[33,54-56]$, it can be concluded that disintegration 
with peracetic acid may shorten the retention time of methane fermentation and increase biogas production.

Figure 11 shows the course of biogas generation, while Figure 12 shows the proportion of methane in biogas expressed in volume percentage during conventional methane fermentation of sludge and methane fermentation of chemically disintegrated sludge.

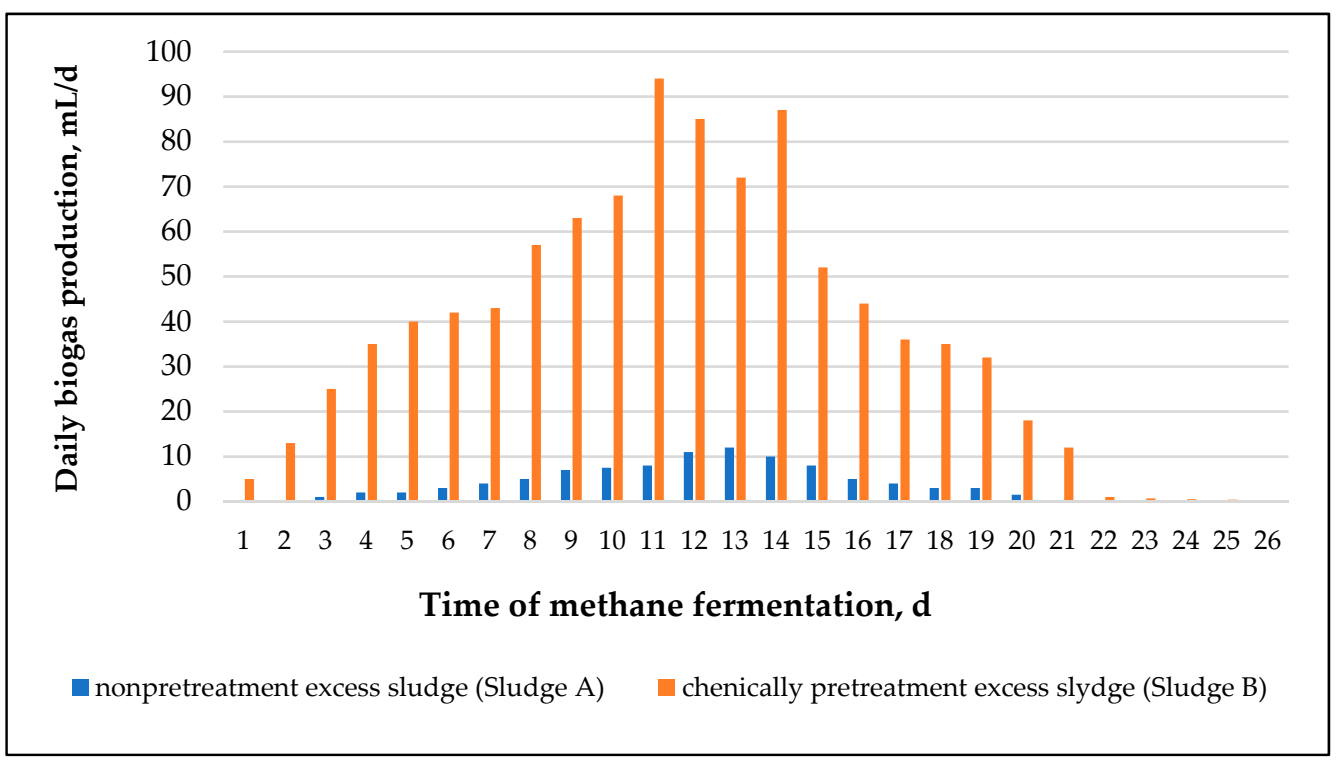

Figure 11. Biogas generation from non-pretreated excess sludge (sludge A) and chemically pretreated excess sludge with the reagent dose of $3.0 \mathrm{~mL}$ STERIDIAL W-10/L (sludge B).

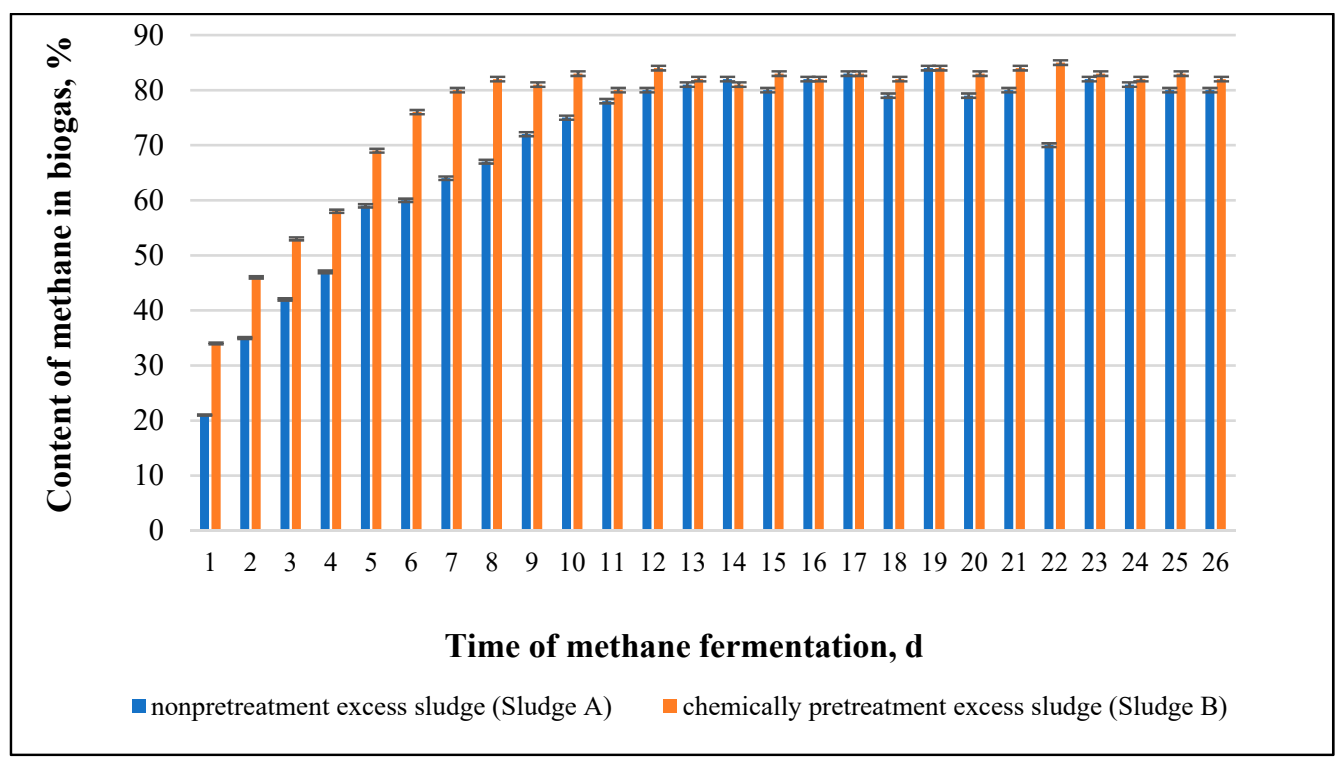

Figure 12. Percentage of methane in biogas expressed as volume percentage recorded during conventional methane fermentation of sludge and methane fermentation of chemically pretreated sludge with the reagent dose of $3.0 \mathrm{~mL}$ STERIDIAL W-10/L.

According to data in the literature, pre-oxidation of sludge with PAA leads to the degradation of extracellular polymer substances and improves the solubility of organic matter and sludge disintegration, thus contributing to increased biogas production $[33,54,57,58]$. 


\section{Conclusions}

The disintegration of excess sludge before methane fermentation plays an important role by supporting the biochemical decomposition of sludge under anaerobic conditions. The use of intracellular substances separated from the cells of activated sludge microorganisms by anaerobic bacteria of methane fermentation occurs only in a dissolved form as a result of the initiation of hydrolysis by disintegrating agents characterized by different types of energy supplied to the sludge.

A novelty aspect of the research is the use of a highly effective method of oxidation of excess sludge with peracetic acid (PAA), taking into account the selection of the most favorable treatment conditions to increase the effectiveness of methane fermentation.

Sludge pretreatment with peracetic acid (PAA) resulted in an increase in soluble chemical oxygen demand and the correlated increase in the concentration of volatile fatty acids, determined in the filtrate fluid of the pretreated sludge. Furthermore, the physicochemical transformation of sludge taking place as a result of sludge pretreatment is reflected in a significant change in the sludge structure expressed by an increase in the degree of particle dispersion. The total and unit biogas production reported during the 26-day anaerobic stabilization of disintegrated sludge and the degree of sludge digestion show, compared to anaerobic stabilization of non-treated sludge, a significant increase in biodegradability of excess sludge treated using the method studied. However, no increase in the calorific value of biogas was found compared to conventional methane fermentation.

It should be emphasized that the potential application of the tested disintegration method in the technological line for sludge disposal offers both ecological and economic benefits resulting from reduced environmental load due to the application of sludge pretreatment, which does not cause secondary pollution.

Author Contributions: Conceptualization, I.Z. and M.W.; methodology, I.Z., software, I.Z. and M.W.; validation, I.Z.; formal analysis, I.Z.; investigation, I.Z.; resources, I.Z. and M.W.; data curation, I.Z.; writing—original draft preparation, I.Z. and M.W.; writing—review and editing, I.Z.; visualization, I.Z.; supervision, M.W.; project administration, I.Z.; funding acquisition, I.Z. and M.W. Both authors have read and agreed to the published version of the manuscript.

Funding: The study was carried out in the framework of the statutory funds for research, financed by the Ministry of Science and Higher Education.

Conflicts of Interest: The authors declare no conflict of interest. The funders had no role in the design of the study; in the collection, analyses, or interpretation of data; in the writing of the manuscript, or in the decision to publish the results.

\section{References}

1. Gonzalez, A.; Hendriks, A.; van Lier, J.B.; de Kreuk, M. Pre-treatments to enhance the biodegradability of waste activated sludge: Elucidating the rate limiting step. Biotechnol. Adv. 2018, 36, 1434-1469. [CrossRef] [PubMed]

2. Deleris, S.; Rouston, J.M. Effect of ozonation on activated sludge solubilization and mineralization. Ozone Sci. Eng. 2000, 22, 473-486. [CrossRef]

3. Lendormi, T.; Prevot, C. Wet oxidation of domestic sludge and process integration: The minerals process. Water Sci. Technol. 2001, 44, 163-169. [CrossRef]

4. Müller, J.A. Prospects and problems of sludge pretreatment processes. Water Sci. Technol. 2001, 44, 121-128. [CrossRef]

5. Ferrer, I.; Ponsá, S.; Vázquez, F.; Font, X. Increasing biogas production by thermal $\left(70^{\circ} \mathrm{C}\right)$ sludge pretreatment prior to thermophilic anaerobic digestion. Biochem. Eng. J. 2008, 42, 186-192. [CrossRef]

6. Wolski, P.; Zawieja, I. Analysis of rheological parameters of pre-conditioned fermented sewage sludge. Annu. Set Environ. Prot. 2013, 15, 1645-1657.

7. Appels, L.; Baeyens, J.; Degrčve, J.; Dewil, R. Principles and potential of the anaerobic digestion of waste-activated sludge. Prog. Energy Combust. Sci. 2008, 34, 755-781. [CrossRef]

8. Ghyoot, W.; Verstraete, W. Anaerobic digestion of primary sludge from chemical pre-precipitation. Water Sci. Technol. 1997, 36, 357-365. [CrossRef]

9. Wolski, P.; Zawieja, I. Effect of ultrasound field on dewatering of sewage sludge. Arch. Environ. Prot. 2012, 38, 25-31. [CrossRef]

10. Wolny, L.; Wolski, P.; Zawieja, I. Rheological parameters of dewatered sewage sludge after conditioning. Desalination 2008, 222, 382-387. [CrossRef] 
11. Bourgrier, C.; Carrére, H.; Delgenés, J.P. Solubilisation of waste-activated sludge by ultrasonic treatment. Chem. Eng. J. 2005, 106, 163-169. [CrossRef]

12. Pilli, S.; Bhunia, P.; Yan, S.; LeBlanc, R.J.; Tyagi, R.D.; Surampalli, R.Y. Ultrasonic pretreatment of sludge: A review. Ultrason. Sonochem. 2011, 18, 1-18. [CrossRef]

13. Zawieja, I.; Wolny, L.; Wolski, P. The impact of the ultrasonic hydrolysis process on the generation of volatile fatty acids in the process of acidic fermentation of excess sludge. Environ. Eng. Prot. 2009, 12, 207-217.

14. Yunqin, L.; Dehan, W.; Shaoquan, W.; Chunmin, W. Alkali pretreatment enhances biogas production in the anaerobic digestion of pulp and paper sludge. J. Hazard. Mater. 2009, 170, 366-373.

15. Myszograj, S. Methane fermentation of thermochemically hydrolysed sewage sludge. Environ. Eng. Prot. 2007, 10, 141-152.

16. Sadecka, Z. Fundamentals of Biological Wastewater Treatment; Seidel-Przywecki: Józefosław, Poland, 2010.

17. Wei, Y.; Van Houten, R.T.; Borger, A.R.; Eikelboom, D.H.; Fan, Y. Minimization of excess sludge production for biological wastewater treatment. Water Res. 2003, 37, 4453-4467. [CrossRef]

18. Kamiya, T.; Hirotsuji, J. New combined system of biological process and intermittent ozonation for advanced wastewater treatment. Water Sci. Technol. 1998, 38, 145-153. [CrossRef]

19. Disintegration of Sewage Sludge. Available online: www.krevox.com.pl (accessed on 7 March 2012).

20. Podedworna, J.; Umiejewska, K. Technology of Sewage Sludge; Publishing House of the Warsaw University of Technology: Warsaw, Poland, 2008.

21. Xu, G.; Chen, S.; Shi, J.; Wang, S.; Zhu, G. Combination treatment of ultrasound and ozone for improving solubilization and anaerobic biodegradability of waste activated sludge. J. Hazard. Mater. 2010, 180, 340-346. [CrossRef] [PubMed]

22. Yeom, I.T.; Lee, K.R.; Lee, Y.H.; Ahn, K.H.; Lee, S.H. Effects of ozone treatment on the biodegradability of sludge from municipal wastewater treatment plants. Water Sci. Technol. 2002, 46, 421-425. [CrossRef]

23. Eskicioglu, C.; Prorot, A.; Marin, J.; Droste, R.L.; Kennedy, K.J. Synergetic pretreatment of sewage sludge by microwave irradiation in presence of $\mathrm{H}_{2} \mathrm{O}_{2}$ for enhanced anaerobic digestion. Water Res. 2008, 42, 4674-4682. [CrossRef]

24. Dell'Erba, A.; Falsanisi, D.; Liberti, L.; Notarnicola, M.; Santoro, D. Disinfection by-products formation during wastewater disinfection with peracetic acid. Desalination 2007, 215, 177-186. [CrossRef]

25. Domínguez Henao, L.; Cascio, M.; Turolla, A.; Antonelli, M. Effect of suspended solids on peracetic acid decay and bacterial inactivation kinetics: Experimental assessment and definition of predictive models. Sci. Total Environ. 2018, 643, 936-945. [CrossRef]

26. Domínguez Henao, L.; Turolla, A.; Antonelli, M. Disinfection by-products formation and ecotoxicological effects of effluents treated with peracetic acid: A review. Chemosphere 2018, 213, 25-40. [CrossRef]

27. Luukkonen, T.; Prokkola, H.; Pehkonen, S.O. Peracetic acid for conditioning of municipal wastewater sludge: Hygienization, odor control, and fertilizing properties. Waste Manag. 2020, 102, 371-379. [CrossRef]

28. Fleck, A. The Investigation of Peracetic Acid-Oxidized Loblolly Pine by Pyrolysis-Gas Chromatography-Mass Spectrometry. Ph.D. Thesis, Georgia Institute of Technology, Atlanta, GA, USA, 1975.

29. Yoon, J.; Lee, Y.; Kim, S. Investigation of the reaction pathway of $\mathrm{OH}$ radicals produced by Fenton oxidation in the conditions of wastewater treatment. Water Sci. Technol. 2001, 44, 15-21. [CrossRef] [PubMed]

30. Braun, A.M.; Oliveros, E. How to evaluate photochemical methods for water treatment. Water Sci. Technol. 1997, 35, 17-23. [CrossRef]

31. Wołczyński, M.; Wiśniowska, E.; Janosz-Rajczyk, M. The influence of conditioning of sewage sludge with peracetic acid on changes in their physical and chemical properties. Environ. Eng. Prot. 2009, 12, 51-63.

32. Shang, M.; Hou, H. Studies on effect of peracetic acid pretreatment on anaerobic fermentation biogas production from sludge. In Proceedings of the Power and Energy Engineering Conference, Wuhan, China, 27-31 March 2009.

33. Appels, L.; Van Assche, A.; Willems, K.; Degreve, J.; Van Impre, J.; Dewil, R. Peractetic acid oxidation as an alternative pre-treatment for the anaerobic digestion of waste activated sludge. Bioresour. Technol. 2011, 102, 4124-4130. [CrossRef]

34. Michalska, K.; Perkowski, J.; Ledakowicz, S.; Kos, L. Decomposition of a concentrated mixture of detergents under the action of Fenton's reagent. Chem. Ind. 2006, 85, 1342-1345.

35. Neis, U. Ultrasound in water, wastewater and sludge treatment. Sewage Treat. 2000, 21, 36-39.

36. Booth, R.A.; Lester, J.N. The potential formation of halogenated by-products during peracetic acid treatment of final sewage effluent. Water Res. 1995, 29, 1793-1801. [CrossRef]

37. Liberti, L.; Notarnicola, M. Advanced treatment and disinfection for municipal wastewater reuse in agriculture. Water Sci. Technol. 1999, 40, 235-245. [CrossRef]

38. Standard PN-91 C-04540/05 Water and Sewage. Tests of pH, Acidity and Mineral and General Alkalinity in Municipal Serwage Sludge; Standardization Publishing House: Warsaw, Poland, 1991.

39. International Measurements Standards ISO 7027. Water Quality; International Organization for Standards: Geneva, Switzerland, 2016.

40. Standard PN-75/C-04616/04 Water and Sewage. Special studies of sediments. In Determination of Volatile Fatty Acids in Sewage Sludge and Over-Sludge Waters by Steam Distillation; Standardization Publishing House: Warsaw, Poland, 1991.

41. Standard PN-EN 12879 Water and Sewage. Special tests of sludge. In Determination of the Content of Water, Dry Matter, Organic Substances and Minerals in Sewage Sludge; Standardization Publishing House: Warsaw, Poland, 1991. 
42. Standard PN-73/C-04576/02 Water and Sewage. Tests for the content of nitrogen compounds. In Determination Of Ammoniacal Nitrogen by Titration Method; Standardization Publishing House: Warsaw, Poland, 1991.

43. Standard PN-75/C-04576/17 Water and Sewage. Tests for the content of nitrogen compounds. In Determination of Total Kjeldahl Nitrogen in Sewage Sludge; Standardization Publishing House: Warsaw, Poland, 1991.

44. Zielewicz, E. Ultrasonic Disintegration of Excess Sludge in Obtaining Volatile Fatty Acids; Publishing House of the Silesian University of Technology: Gliwice, Poland, 2007.

45. Baier, U.; Schmidheiny, P. Enhanced anaerobic degradation of mechanically disintegrated sludge. Water Sci. Technol. 1997, 36, 137-143. [CrossRef]

46. Polish Standards PN-75/C-04616/07, Water and Sewage. Special Tests of Sludge, Determination of the Fermentation Capacity of Sewage Sludge and the Degree of Its Fermentation under Static Conditions and in a Continuous Process; Standardization Publishing House: Warsaw, Poland, 2019.

47. Fukas-Płonka, Ł.; Zielewicz-Madej, E. Stabilization of excess sludge in the methane fermentation process. Environ. Eng. Prot. 2000, 3, 37-48.

48. Stanisz, A. An Accessible Course in Statistics with the Use of STATISTICA PL on Examples from Medicine; StatSoft Polska Publishing House: Cracow, Poland, 2006.

49. Procházka, J.; Dolejš, P.; MácA, J.; Dohányos, M. Stability and inhibition of anaerobic processes caused by insufficiency or excess of ammonia nitrogen. Appl. Microbiol. Biotechnol. 2012, 93, 439-447. [CrossRef]

50. Cavallini, G.S.; De Campos, S.X.; De Souza, J.B.; De Sousa Vidal, C.M. Evaluation of the physical-chemical characteristics of wastewater after disinfection with peracetic acid. Water Air Soil Pollut. 2013, 224, 1752. [CrossRef]

51. Magrel, L. Methodology for Assessing the Effectiveness of the Methane Fermentation Process of Selected Sewage Sludge; Publishing House of the Bialystok University of Technology: Bialystok, Poland, 2002.

52. Heidrich, Z. Water Supply and Sewage Systems; School and Pedagogical Publishers: Warsaw, Poland, 1999.

53. Chu, C.P.; Lee, D.J.; You, C.S.; Tay, J.H. Weak ultrasonic pre-treatment on anaerobic digestion of flocculated activated biosolids. Water Res. 2002, 36, 2681-2688. [CrossRef]

54. Sun, D.; Qiao, M.; Xu, Y.; Ma, C.; Zhang, X. Pretreatment of waste activated sludge by peracetic acid oxidation for enhanced anaerobic digestion. Environ. Prog. Sustain. Energy 2018, 37, 2058-2062. [CrossRef]

55. Zhou, A.; Zhang, J.; Varrone, C.; Wen, K.; Wang, G.; Liu, W.; Wang, A.; Yue, X. Process assessment associated to microbial community response provides insight on possible mechanism of waste activated sludge digestion under typical chemical pretreatments. Energy 2017, 137, 457-467. [CrossRef]

56. Zhang, W.; Cao, B.; Wang, D.; Ma, T.; Xia, H.; Yu, D. Influence of wastewater sludge treatment using combined peroxyacetic acid oxidation and inorganic coagulants re-flocculation on characteristics of extracellular polymeric substances (EPS). Water Res. 2016, 88, 728-739. [CrossRef] [PubMed]

57. Kwarciak-Kozłowska, A.; Włodarczyk, R. Efficiency assessment of coke industry wastewater treatment during advanced oxidation process with biochar adsorption. Desalin. Water Treat. 2020, 199, 441-450. [CrossRef]

58. Kwarciak-Kozłowska, A.; Fijałkowski, K. Efficiency assessment of municipal landfill leachate treatment during advanced oxidation process (AOP) with biochar adsorption (BC). J. Environ. Manag. 2021, 287, 112309. [CrossRef] [PubMed] 